\title{
Research on the Educational Mode of Chinese Piano Works in Piano Teaching in Colleges and Universities
}

\author{
Mingna Wang \\ Academy of Music Chongqing Nanfang Translators College of Sisu, Chongqing, China, 400000.
}

Keywords: Chinese style piano works; piano teaching in colleges and universities; application; meaning

\begin{abstract}
For a long time, western works have dominated the piano teaching in colleges and universities, while Chinese piano works have received a cold reception. In recent years, along with the overall progress and development of the piano industry, the value of Chinese piano works and their significance in teaching have also been re-recognized, and they play an irreplaceable role in students' playing concepts and techniques. Therefore, it is necessary to strengthen the learning status of Chinese-style piano works in teaching, so that students can learn and understand Chinese-style piano works on their own initiative. This paper systematically analyzes the significance of Chinese-style piano works in the piano teaching in colleges and universities, and discusses the application of the education mode of Chinese-style piano works in the piano teaching in colleges and universities, so as to strengthen students' learning of Chinese piano music, carry forward the Chinese nation's music culture, and promote the steady development of Chinese piano cause.
\end{abstract}

\section{Introduction}

At present, in the piano teaching of Chinese universities, domestic piano works have not received enough attention in terms of quantity and style. In the form of teaching, teaching is still carried out in Western piano works. The proportion of Chinese piano works is not large, which directly affects the understanding of college students on their national music and culture. In order to highlight the characteristics of China's higher education, domestic piano works should be selected into the university piano teaching content. We should actively spread Chinese piano works in the university and actively inherit and carry forward outstanding national culture. In this way, not only can students effectively enhance their artistic accomplishment and improve their piano professional skills, but they can also cultivate and enhance students' national music cognition and emotions, and promote the improvement of teaching efficiency and quality ${ }^{[1]}$.

\section{The significance of Chinese piano works in piano teaching in colleges and universities}

\subsection{Contribute to the richness and improvement of students' piano playing techniques}

Allowing students to master solid and comprehensive piano playing techniques is undoubtedly an important goal of college piano teaching. From the practical point of college piano teaching, the 
teaching is based on Western works, so the students are also learning techniques based on playing Western works. But the piano is known as the "king of musical instruments" and has an unparalleled musical expression. Especially after its introduction to China, many creators have combined it with traditional Chinese music to create Chinese piano works that are quite different from Western works. Therefore, through the performance of Chinese piano works, students' performance techniques will be enriched and improved. Take Wang Jianzhong's "Three Plum Blossoms" as an example, which is adapted from the Chinese ancient lyrics of the same name. In the works, there are many imitations of the guqin. In order to obtain good timbre effects, some innovative techniques must be used to create an empty and distant artistic conception. Sometimes it's just a touch of a button, it will show a different charm because of the difference in direction and strength. These are not seen in Western piano works, but also the enrichment and improvement of students' playing skills ${ }^{[2]}$. Table 1 is a comparison of Western piano works and Chinese style piano works.

Table 1 Differences between Chinese and Western piano music works

\begin{tabular}{|c|c|c|}
\hline aspect & Chinese style piano & Western piano \\
\hline Rhythm and beat & Non-uniform rhythm & Functionally equal division \\
\hline harmony & Mostly mono music & Multi-voice \\
\hline tone & the tone changes greatly & the tone changes little \\
\hline structure & $\begin{array}{c}\text { Unordered to ordered to } \\
\text { unordered }\end{array}$ & The ABA syllogism \\
\hline
\end{tabular}

\subsection{Contribute to the inheritance and development of national music culture}

Since the introduction of the piano into China, Chinese creators have begun the process of transforming their nationalization. Many outstanding Chinese piano works are the crystallization of this transformation. There are many works that are closely related to traditional Chinese music culture. For example, a large number of piano adaptations are based on traditional music, which not only brings the distance between the piano and the Chinese people closer, but also objectively promotes the spread of traditional music culture. Today in the 21st century is an era of cultural diversification. The importance of national music education has been recognized in many aspects, but its development is not smooth. The introduction of a large number of Chinese piano works in college piano teaching is an effective form of national music education. When students play these works, they can not only understand the traditional music culture, but also experience the oriental music thinking unique to the original and the adaptors. This will lay a good foundation for students to enjoy the inheritance of national music and national music.

\subsection{Help students develop national pride and self-confidence}

For a long time, college piano teaching has been dominated by Western works, which has greatly affected students' musical values. They have fallen into a misunderstanding of "only Western works" and believe that only Western piano works are the best. The most authentic. As everyone knows, our national piano works are not inferior to the artistic charm of Western works, and they showcase the hard work, wisdom and unyielding of the Chinese nation. The piano concerto "Yellow River", known as "the strongest sound of Chinese piano", shows the feat of the Chinese people's struggle for national freedom and independence during the revolutionary war. I believe that everyone who has heard and played this work will be impressed by this national spirit, a kind of national self-confidence and pride. Therefore, Chinese piano works are not isolated, but are organically associated with the times, society, culture and many other aspects. Through the 
appreciation and performance of these works, students' patriotic feelings can be fully stimulated and their national self-confidence and pride can be cultivated. This is also an important purpose of piano teaching ${ }^{[3]}$.

\section{The application of Chinese style piano works in college piano teaching}

\subsection{Play a teacher role}

Piano teachers are people who face students directly, and their personal behaviors and ideas often have a direct impact on students. Therefore, teachers themselves should pay full attention to national music, establish a good national music aesthetics, love traditional music culture, and constantly learn and improve themselves, and organize and carry out Chinese piano teaching in a planned, multi-path, and targeted manner. In terms of teaching and research, lectures and other activities, the system comprehensively cultivates and enhances the teaching quality and skills of the Chinese piano works, carefully studies and analyzes the works and teaching materials, and gives full play to the leading role of teachers, allowing students to better learn Chinese piano works.

\subsection{Clear syllabus}

The syllabus is a guide for the development of teaching activities, and it is also the main basis for teachers' teaching. This is the programmatic document formulated by the education management department. Teachers, students and schools must strictly implement it. However, in the current piano syllabus of most colleges and universities, there are few expressions on the selection and teaching of Chinese piano works. Although more and more piano teachers have realized the importance of Chinese piano works in teaching, teachers often do not consciously and easily change their personal teaching habits because of the lack of practical guidance and basis, or the lack of uniform documents ${ }^{[4]}$.

To promote the teaching of Chinese piano works, it should be included in the syllabus to be clear, as clearly as Table 2. Specifically: First, the fundamental purpose and significance of learning and playing Chinese piano works, so that teachers and students can fully understand the importance of Chinese piano works in teaching. Second, during the study and practice, each stage of the student should be able to master and play a certain number of Chinese piano works, and can explain the content of the work to achieve the teaching objectives. The third is to develop scientific and reasonable assessment methods to effectively test the learning effect of students. The fourth is to clarify the way in which Chinese piano works are taught. If you take a group class to introduce and recommend relevant materials to students, you can ask for the necessary listening tracks when necessary, and regularly carry out class or professional piano concerts to enable students to fully communicate. In this way, students can better understand Chinese piano works.

Table 2 Teaching content of Chinese piano works

\begin{tabular}{|ll|}
\hline \multicolumn{2}{|l|}{ Chinese style piano works introduced to college piano teaching } \\
\hline$\bullet$ & Understanding the Importance of Chinese Piano Works in Teaching \\
\hline$\bullet$ & Playing a certain number of Chinese piano works \\
\hline$\bullet$ & Develop scientific and reasonable assessment methods \\
\hline$\bullet$ & Defining the way to teach Chinese piano works \\
\hline
\end{tabular}

\subsection{Enhanced technical training}

In the performance of Chinese piano works, most of the techniques and playing requirements are 
consistent with the playing techniques of Western piano works, but because Chinese music has its own scale, five-tone, harmony and polyphonic application rules and The method, therefore, Chinese piano works have many performance techniques and expression techniques that are not available in Western piano works. Among them, especially the fingering difference is the most significant. For example, in the performance of Chinese piano works, there is a need to use the finger to play the small three-degree five-tone progressive habit, so that the finger and the finger can be used flexibly. In the continuous scale, the finger span is larger. The main application of the hands is three or six degrees in parallel, and the most common in parallel is four or five degrees. The non-three-degree superposition of chords makes the chord fingering more complicated, and requires a clear touch of the fingers. Usually, the sounds and techniques have different effects on the playing method. At the same time, in the aspect of decorative sound processing, there are quantitative standards for Western piano works, but there is no such standard in Chinese piano works, which is effectively grasped only through the understanding of music ${ }^{[5]}$.

Chinese piano works have given a variety of playing and expression techniques for piano performance, and should be carefully and meticulously studied and studied in practical teaching. It is necessary to fully understand and apply the aesthetic principles of traditional music, based on profound national culture, and fully demonstrate the national characteristics and artistic characteristics of the works. Therefore, only by carefully comparing and carefully tasting in teaching can students' music comprehension, perception and expressiveness be better cultivated.

\section{Conclusions}

In the piano teaching in colleges and universities, the importance of Chinese style piano works should be paid full attention to and placed in an important position. It is also a way to carry forward national culture to actively and deeply select excellent Chinese piano works and systematically and effectively introduce them into piano teaching in colleges and universities. Only by strengthening and promoting the teaching of Chinese piano works in colleges and universities, and improving the teaching efficiency of Chinese piano works, can the teaching level be further improved, so as to better promote the healthy and orderly development of Chinese piano music creation and music art.

\section{References}

[1] Hu Wei. Analysis of the Importance of Chinese Piano Works in College Piano Teaching [J]. Journal of Xingyi Nationalities Normal University, 2016(4):90-92.

[2] Li Xiao. The Significance of Chinese Piano Works in Piano Teaching in Colleges and Universities [J]. Heilongjiang Science, 2017, 8(11): 134-135.

[3] Chen Jing. Problems and Strategies in Piano Music Teaching Performing Arts [J]. Art Education, 2014(12):138-138.

[4] Sun Yun. The Chinese Style at the Fingertips-Discussion on the Performance Characteristics and Style of Chinese-style Piano Works [J]. Sound of the Yellow River, 2017(10): 54-55

[5] Zhang Yuwen. A Brief Discussion on the Application of Chinese Style in Piano Works [J]. Modern Vocational Education, 2017(21). 